\title{
An ionic liquid consisting of crown ether-coordinated hydronium cation and amide anion
}

\section{AUTHOR(S):}

Takeoka, Shun; Kitada, Atsushi; Fukami, Kazuhiro; Murase, Kuniaki

\section{CITATION:}

Takeoka, Shun ...[et al]. An ionic liquid consisting of crown ether-coordinated hydronium cation and amide anion. ECS Transactions 2016, 75(15): 239-244

\section{ISSUE DATE:}

2016

URL:

http://hdl.handle.net/2433/259841

\section{RIGHT:}

This is the Accepted Manuscript version of an article accepted for publication in ECS Transactions. The Electrochemical Society and IOP Publishing Ltd are not responsible for any errors or omissions in this version of the manuscript or any version derived from it. The Version of Record is available online at https://doi.org/10.1149/07515.0239ecst;; この論文は 出版社版でありません。引用の際には出版社版をご確認ご利用ください。; This is not the published version. Please cite only the published version. 


\title{
An Ionic Liquid Consisting of Crown Ether-Coordinated Hydronium Cation and Amide Anion
}

\author{
S. Takeoka, A. Kitada, K. Fukami, and K. Murase \\ Department of Materials Science and Engineering, Graduate School of Engineering, \\ Kyoto University, Kyoto, 606-8501, Japan
}

\begin{abstract}
We first report an ionic liquid (IL) that consists of hydronium $\left(\mathrm{H}_{3} \mathrm{O}^{+}\right)$ion encapsulated by 18-crown-6-ether (18C6) and an amide anion. The composition of the crown ether-coordinated hydronium amide IL was estimated to be as $\left[\mathrm{H}_{3} \mathrm{O}^{+} \cdot 18 \mathrm{C} 6\right]\left[\mathrm{Tf}_{2} \mathrm{~N}^{-}\right]$. The presence of $\mathrm{H}_{3} \mathrm{O}^{+}$was revealed from the characteristic bands of the hydronium ion present in the infrared spectra. The melting point of $\left[\mathrm{H}_{3} \mathrm{O}^{+} \cdot 18 \mathrm{C} 6\right]\left[\mathrm{Tf}_{2} \mathrm{~N}^{-}\right]$was $68-70{ }^{\circ} \mathrm{C}$. At $70{ }^{\circ} \mathrm{C}$, the viscosity of $\left[\mathrm{H}_{3} \mathrm{O}^{+} \cdot 18 \mathrm{C} 6\right]\left[\mathrm{Tf}_{2} \mathrm{~N}^{-}\right]$was $39.5 \mathrm{mPa} \mathrm{s}$, the conductivity was $1.9 \mathrm{mS} \mathrm{cm} \mathrm{cm}^{-1}$, and the density was about $1.32 \mathrm{~g}$ $\mathrm{cm}^{-3}$. These bath properties of $\left[\mathrm{H}_{3} \mathrm{O}^{+} \cdot 18 \mathrm{C} 6\right]\left[\mathrm{Tf}_{2} \mathrm{~N}^{-}\right]$were similar to those of common ILs at room temperature.
\end{abstract}

\section{Introduction}

Ionic liquids (ILs) are salts which melt below $100{ }^{\circ} \mathrm{C}$, and consist of a cation and an anion with low charge density. ILs have attracted remarkable attention as new materials for various chemical applications. There are reports on ILs which consist of strongly Lewis-acidic metal cations such as lithium ion and potassium ion coordinated by ether-ligands to decrease charge density (1-2). A cyclic hexamer of ethylene oxide 1,4,7,10,13,16-hexaoxacyclooctadecane (18-crown-6-ether, hereafter referred to as 18C6) has a suitable cavity for encapsulation of potassium ion and hydronium $\left(\mathrm{H}_{3} \mathrm{O}^{+}\right)$ ion (3-4). Various compounds with $\mathrm{H}_{3} \mathrm{O}^{+}$encapsulated by $18 \mathrm{C} 6$ ligand $\left(\left[\mathrm{H}_{3} \mathrm{O}^{+} \cdot 18 \mathrm{C} 6\right]\right.$ cation) have been reported, the counteranions of which are such as hexafluorophosphate $\left(\mathrm{PF}_{6}{ }^{-}\right)$, tetrafluoroborate $\left(\mathrm{BF}_{4}^{-}\right)$and trifluoromethylsulfonate $\left(\mathrm{TfO}\right.$; $\left.\mathrm{Tf}=\mathrm{CF}_{3} \mathrm{SO}_{2}\right)$ ions (3-4). However, their melting points are higher than $100{ }^{\circ} \mathrm{C}$. Furthermore, as far as we know, nothing has been reported on combination of $\left[\mathrm{H}_{3} \mathrm{O}^{+} \cdot 18 \mathrm{C} 6\right]$ cation and bis(trifluoromethylsulfonyl)amide $\left(\mathrm{Tf}_{2} \mathrm{~N}^{-}\right)$anion. In this paper, we report a synthesis of a complex with $\left[\mathrm{H}_{3} \mathrm{O}^{+} \cdot 18 \mathrm{C} 6\right]$ cation and an amide anion, whose melting point was about $70{ }^{\circ} \mathrm{C}$. 


\section{Experimental}

$5 \mathrm{mmol}$ of 18C6 (Kanto Chemical, 99\% purity) and 5 mmol of $\mathrm{HTf}_{2} \mathrm{~N}$ (Aldrich, $\geq 95 \%$ purity) in $5 \mathrm{~mL}$ of water were stirred at $500 \mathrm{rpm}$ and heated at $50{ }^{\circ} \mathrm{C}$ for 1 day, followed by vacuum-drying at $50{ }^{\circ} \mathrm{C}$ for 3 days. The obtained complex was a white solid at room temperature and a colorless transparent liquid at about $70{ }^{\circ} \mathrm{C}$ (see Figure 1). The composition of the complex was determined using elemental analysis and KarlFischer titration. The presence of $\mathrm{H}_{3} \mathrm{O}^{+}$was checked with infrared spectra (JASCO, FT/IR-460 plus). For the infrared measurement, Nujol and hexachlorobutadiene mulls painted on a barium fluoride window were used at room temperature. In order to evaluate the complex as an IL, we measured the density, the viscosity, the conductivity, and the melting point. The melting point of the complex was evaluated by differential scanning calorimeter (Shimadzu, DSC-60) with a sweeping rate of $5{ }^{\circ} \mathrm{C} \mathrm{min}^{-1}$ by heating from room temperature up to $80^{\circ} \mathrm{C}$ and then cooling down to $40^{\circ} \mathrm{C}$.
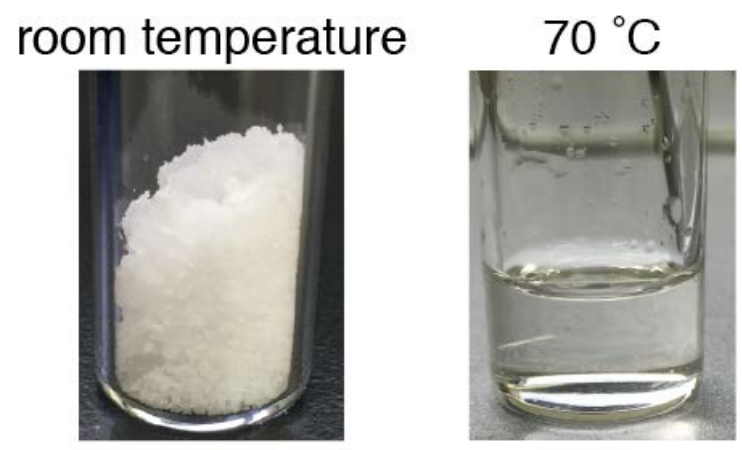

Figure 1. Photographs of the obtained complex at room temperature and $70{ }^{\circ} \mathrm{C}$.

\section{Results and discussion}

TABLE I shows elemental analysis results for $\mathrm{H}, \mathrm{C}, \mathrm{N}, \mathrm{F}$, and $\mathrm{S}$. The experimental value was in good agreement with the calculated value assuming that the complex was 18C6: $\mathrm{H}_{2} \mathrm{O}: \mathrm{HTf}_{2} \mathrm{~N}=1: 1: 1$. The $\mathrm{H}_{2} \mathrm{O}$ content of the complex was 3.29 wt\% analyzed by Karl-Fischer titration, in good agreement with the calculated value (3.20 wt\%). Therefore, it is concluded that the complex consists of equimolar amount of 18C6, $\mathrm{H}_{2} \mathrm{O}$, and $\mathrm{HTf}_{2} \mathrm{~N}$.

TABLE I. Elemental analysis results for the obtained sample.

\begin{tabular}{cccccc}
\hline The complex & H (\%) & C (\%) & N (\%) & F (\%) & S (\%) \\
\hline \hline Calculated & 4.80 & 29.84 & 2.49 & 20.25 & 11.37 \\
Experimental & 4.90 & 29.97 & 2.40 & 20.07 & 11.35 \\
\hline
\end{tabular}


The presence of $\mathrm{H}_{3} \mathrm{O}^{+}$readily established from the characteristic bands of the hydronium ion present in the high-wavenumber region from $1600 \mathrm{~cm}^{-1}$ to $4000 \mathrm{~cm}^{-1}$ of infrared spectra (Figure 2). The bands due to $\mathrm{H}_{3} \mathrm{O}^{+}$are reported to be $2780-3250 \mathrm{~cm}^{-1}$ $\left(v_{1}\right), 1048-1182 \mathrm{~cm}^{-1}\left(v_{2}\right), 2500-3100 \mathrm{~cm}^{-1}\left(v_{3}\right)$, and $1477-1705 \mathrm{~cm}^{-1}\left(v_{4}\right)(5-6)$. The $v_{1}$ and $v_{3}$ stretching modes of the complex gave the very broad band centered at $2920 \mathrm{~cm}^{-1}$, which overlapped the sharper maximum arising from the $\mathrm{C}-\mathrm{H}$ stretching motions of $18 \mathrm{C} 6$ at $2880 \mathrm{~cm}^{-1}$. The band at $1650 \mathrm{~cm}^{-1}$ was attributable to the $v_{4}$ bending mode. The characteristic band also appeared at $2200 \mathrm{~cm}^{-1}$, attributable to the first harmonic of $v_{2}$, i.e. symmetric bending mode $(4,7)$. The $v_{2}$ band at $1100 \mathrm{~cm}^{-1}$ was not clearly observed, where a strong band from 18C6 overlapped (7). When water was added to the complex, a broad band appeared at 3200-3600 $\mathrm{cm}^{-1}$ (not shown). Therefore, the broad band observed at $3480 \mathrm{~cm}^{-1}$ for pure 18C6 was attributable to unprotonated water (8). The water content of pure 18C6 was 0.14 wt $\%$ analyzed by Karl-Fischer titration. In the infrared spectra of the complex, the broad band at $3480 \mathrm{~cm}^{-1}$ due to unprotonated water disappeared and the sharp band appeared at $3570 \mathrm{~cm}^{-1}$, which may be due to the formation of $\left[\mathrm{H}_{3} \mathrm{O}^{+} \cdot 18 \mathrm{C} 6\right]$. Consequently, the complex hardly includes unprotonated water.

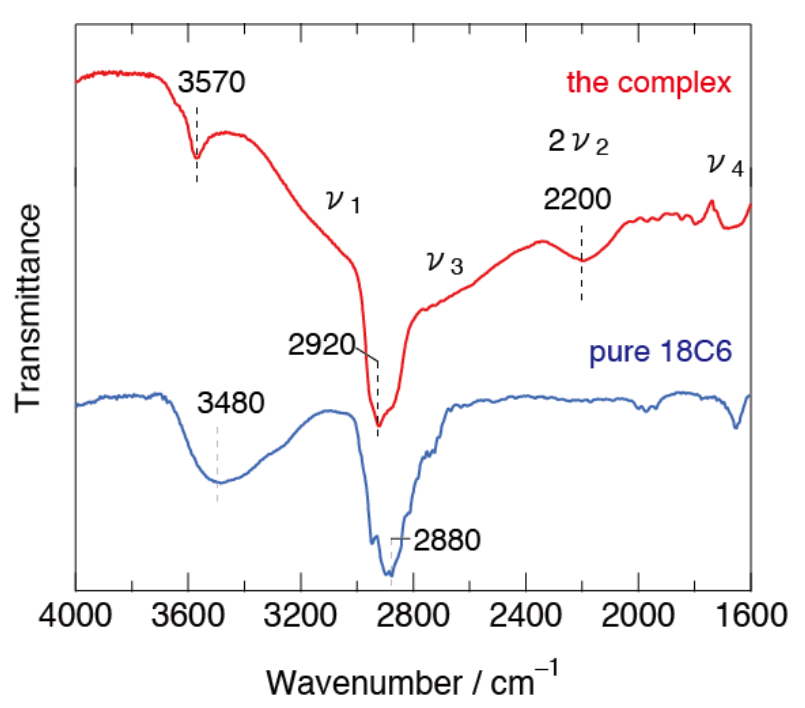

Figure 2. High-wavenumber region from $1600 \mathrm{~cm}^{-1}$ to $4000 \mathrm{~cm}^{-1}$ of the infrared spectrum of the complex (expected as $\left[\mathrm{H}_{3} \mathrm{O}^{+} \cdot 18 \mathrm{C} 6\right]\left[\mathrm{Tf}_{2} \mathrm{~N}^{-}\right]$) and pure $18 \mathrm{C} 6$ mulled in hexachlorobutadiene.

Figure 3 shows the infrared spectra of the complex and pure $18 \mathrm{C} 6$ in the low-wavenumber region from $800 \mathrm{~cm}^{-1}$ to $1400 \mathrm{~cm}^{-1}$. The broad band at $1125 \mathrm{~cm}^{-1}$ of pure 18C6 was the $\mathrm{C}-\mathrm{O}-\mathrm{C}$ stretching absorption of 18C6. In the infrared spectra of the complex, the broad band at $1125 \mathrm{~cm}^{-1}$ of 18C6 disappeared and split into sharp bands at $1138 \mathrm{~cm}^{-1}$ and $1091 \mathrm{~cm}^{-1}$ because of $\left[\mathrm{H}_{3} \mathrm{O}^{+} \cdot 18 \mathrm{C} 6\right]$ formation (4). From these 
experiments, the formulation of the complex was estimated to be as $\left[\mathrm{H}_{3} \mathrm{O}^{+} \cdot 18 \mathrm{C} 6\right]\left[\mathrm{Tf}_{2} \mathrm{~N}^{-}\right]$. The schematic structure of which is shown in Figure 4.

Figure 5 shows differential scanning calorimeter (DSC) thermograms of $\left[\mathrm{H}_{3} \mathrm{O}^{+} \cdot 18 \mathrm{C} 6\right]\left[\mathrm{Tf}_{2} \mathrm{~N}^{-}\right]$sample. The melting point of $\left[\mathrm{H}_{3} \mathrm{O}^{+} \cdot 18 \mathrm{C} 6\right]\left[\mathrm{Tf}_{2} \mathrm{~N}^{-}\right]$was $68-70{ }^{\circ} \mathrm{C}$. The melting point of pure $18 \mathrm{C} 6$ and of pure $\mathrm{HTf}_{2} \mathrm{~N}$ are $40{ }^{\circ} \mathrm{C}$ and $52-58{ }^{\circ} \mathrm{C}$, but endothermal reaction below $60{ }^{\circ} \mathrm{C}$ were not observed in Figure 5. Therefore, it was concluded that $\left[\mathrm{H}_{3} \mathrm{O}^{+} \cdot 18 \mathrm{C} 6\right]\left[\mathrm{Tf}_{2} \mathrm{~N}^{-}\right]$neither included isolated $18 \mathrm{C} 6$ nor $\mathrm{HTf}_{2} \mathrm{~N}$.

At $70{ }^{\circ} \mathrm{C}$, the viscosity of $\left[\mathrm{H}_{3} \mathrm{O}^{+} \cdot 18 \mathrm{C} 6\right]\left[\mathrm{Tf}_{2} \mathrm{~N}^{-}\right]$was $39.5 \mathrm{mPa}$, the conductivity was $1.9 \mathrm{mS} \mathrm{cm}$, and the density was about $1.32 \mathrm{~g} \mathrm{~cm}^{-3}$. These bath properties of $\left[\mathrm{H}_{3} \mathrm{O}^{+} \cdot 18 \mathrm{C} 6\right]\left[\mathrm{Tf}_{2} \mathrm{~N}^{-}\right]$were similar to those of common ILs at room temperature. Therefore, $\left[\mathrm{H}_{3} \mathrm{O}^{+} \cdot 18 \mathrm{C} 6\right]\left[\mathrm{Tf}_{2} \mathrm{~N}^{-}\right]$was characterized as an IL.

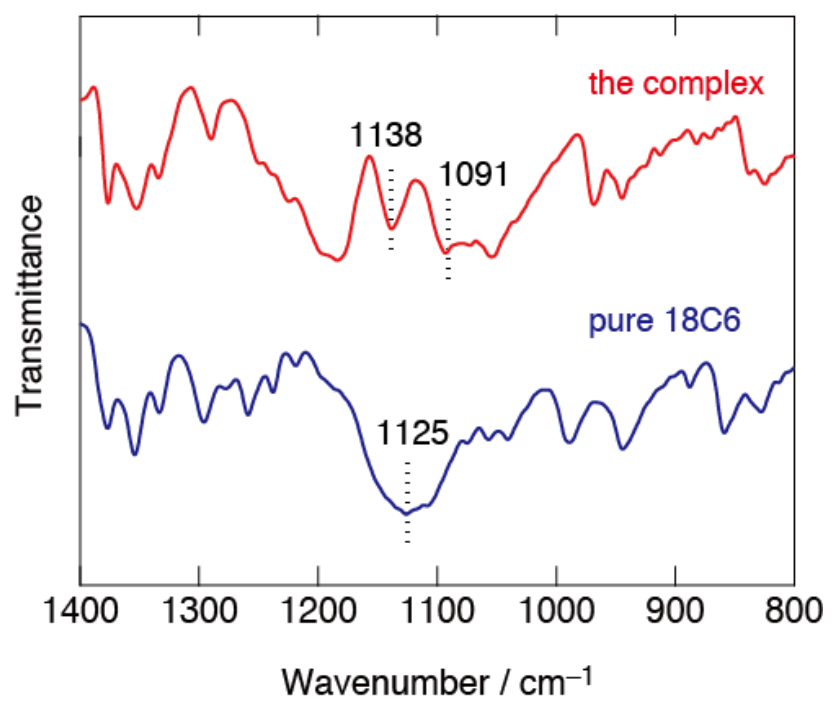

Figure 3. Low-wavenumber region from $800 \mathrm{~cm}^{-1}$ to $1400 \mathrm{~cm}^{-1}$ of the infrared spectra of the complex (expected as $\left[\mathrm{H}_{3} \mathrm{O}^{+} \cdot 18 \mathrm{C} 6\right]\left[\mathrm{Tf}_{2} \mathrm{~N}^{-}\right]$) and pure $18 \mathrm{C} 6$ mulled in Nujol.

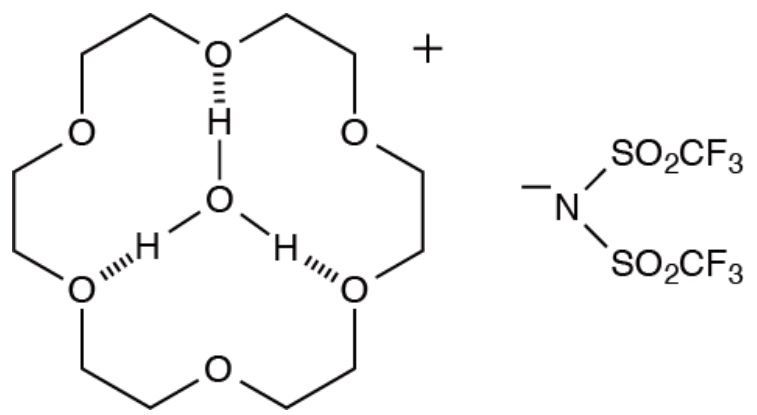

Figure 4. Schematic structure of $\left[\mathrm{H}_{3} \mathrm{O}^{+} \cdot 18 \mathrm{C} 6\right]\left[\mathrm{Tf}_{2} \mathrm{~N}^{-}\right]$. 


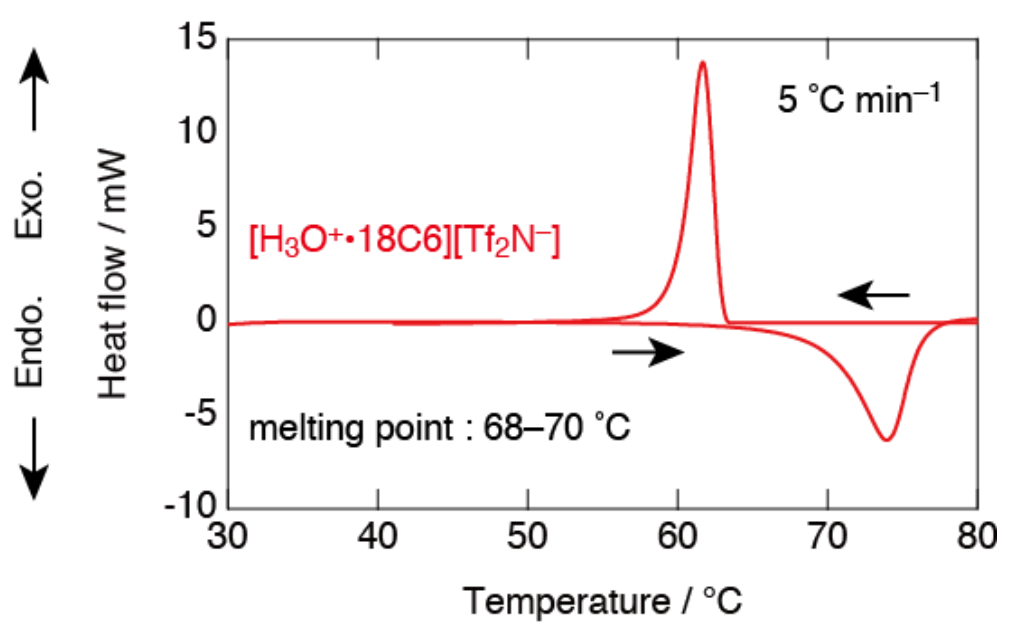

Figure 5. DSC thermograms of $24.6 \mathrm{mg}$ of the $\left[\mathrm{H}_{3} \mathrm{O}^{+} \cdot 18 \mathrm{C} 6\right]\left[\mathrm{Tf}_{2} \mathrm{~N}^{-}\right]$placed in a hermetically sealed aluminum pan.

\section{Conclusions}

In conclusion, we synthesized a new IL consisting of $\mathrm{H}_{3} \mathrm{O}^{+}$cation encapsulated by 18C6 and an amide anion, of which melting point was below $100{ }^{\circ} \mathrm{C}$. The obtained complex was concluded as $\left[\mathrm{H}_{3} \mathrm{O}^{+} \cdot 18 \mathrm{C} 6\right]\left[\mathrm{Tf}_{2} \mathrm{~N}^{-}\right]$. The bath properties of $\left[\mathrm{H}_{3} \mathrm{O}^{+} \cdot 18 \mathrm{C} 6\right]\left[\mathrm{Tf}_{2} \mathrm{~N}^{-}\right]$at $70{ }^{\circ} \mathrm{C}$ were similar to those of common ILs at room temperature. In the infrared spectra, it was revealed that $\mathrm{H}_{3} \mathrm{O}^{+}$of the obtained complex was encapsulated by $18 \mathrm{C} 6$. In addition, $\left[\mathrm{H}_{3} \mathrm{O}^{+} \cdot 18 \mathrm{C} 6\right]\left[\mathrm{Tf}_{2} \mathrm{~N}^{-}\right]$hardly includes unprotonated water. Further study is needed to reveal other properties of $\left[\mathrm{H}_{3} \mathrm{O}^{+} \cdot 18 \mathrm{C} 6\right]\left[\mathrm{Tf}_{2} \mathrm{~N}^{-}\right]$.

\section{Acknowledgments}

This work was financially by Grant-in-Aid for Scientific Research (A) (No. 25249106 and No. 16H02411), Grant-in-Aid for challenging Exploratory Research (No. 15K14193), and Grant-in-Aid for Young Scientists (B) (No. 15K18253) from the Japan Society for the Promotion of Science (JSPS). A.K also thanks Izumi Science and Technology Foundation for their financial support (No. H27-J-080).

\section{References}

1. T. Tamura, K. Yoshida, T. Hachida, M. Tsuchiya, M. Nakamura, Y. Kazue, N. Tachikawa, K. Dokko, and M. Watanabe, Chem. Lett., 39, 753 (2010).

2. Y. Song, H. Jing, B. Li, and D. Bai, Chem. Eur. J., 17, 8731 (2011). 
3. R. Chénevert, A. Rodrigue, M. Pigeon-Gosselin, and R. Savoie, Can. J. Chem., 60, 853 (1982).

4. G. S. Heo and R. A. Bartsch, J. Org. Chem., 47, 3557 (1982).

5. R. D. Gillard and G. Wilkinson, J. Chem. Soc., 1640 (1964).

6. R. Savoie and P. A. Giguere, J. Chem. Phys., 41, 2698 (1964).

7. R. Chénevert, A. Rodrigue, P. Beauchesne, and R. Savoie, Can. J. Chem., 62, 2293 (1984).

8. B. I. El-Eswed, M. B. Zughul, and G. A. W. Derwish, J. Incl. Phenom., 28, 245 (1997). 